ПЕДАГОГІЧНІ УМОВИ ПРОФЕСІЙНОЇ ПІДГОТОВКИ
МАЙБУТНЬОГО ВЧИТЕЛЯ ІНОЗЕМНОЇ МОВИ
ДО ПРОФІЛЬНОГО НАВЧАННЯ СТАРШОКЛАСНИКІВ

\title{
PEDAGOGICAL CONDITIONS OF VOCATIONAL TRAINING OF FUTURE TEACHER OF A FOREIGN LANGUAGE FOR SPECIALIZED TRAINING OF HIGH SCHOOL STUDENTS
}

\begin{abstract}
У статmі розкрито сутність поняття «умова» та охарактеризовано зміст терміна «педагогічні умови». На основі узагальнення наукових підходів учених визначено зміст поняття «педагогічні умови підготовки майбутніх учителів іноземної мови до профрільного навчання старшокласників»: реалізація компетентнісного підходу у прочесі моделювання змісту підготовки майбутніх учителів іноземної мови до профрільного навчання старшокласників; впровадження інноваційних технологій у процес формування професійної компетентності майбутнього вчителя іноземної мови; срормування професійної рефлексії в майбутніх учителів іноземної мови засобами самооцінки готовності до профрільного навчання старшокласників.
\end{abstract}

Уконтексті проблеми дослідження поняття «підготовка майбутніх учителів іноземноі мови» розглядаємо як безперервний, цілісний, системний і керований освітній прочес, який забезпечує готовність студентів до просресійно-педагогічної діяльності та сорормованість інтегрованого особистісного утворення, що містить у своїй структурі мотиваційно-ціннісний, когнітивноопераційний, рефрлексивний, діяльнісний, особистісний компоненти.

Важливо зазначити, що для характеристики поняття «профресійно-педагогічна готовність» вчені використовують поняття «професійна компетентність», яке визначається як професійна готовність i здатність суб'єкта праці до виконання завдань і обов'язків повсякденної діяльності. Результатом підготовки майбутніх учителів до професійної діяльності є певний рівень готовності до професійної діяльності, активно-діяльнісний стан особистості, що охоплює позитивне ставлення до просресії, здібності, знання, вміння, навички, стійкі професійно важливі якості. Профресійна готовність майбутнього вчителя іноземно мови до педагогічної діяльності характеризується його професійною кваліфрікацією та певною сукупністю особистісних якостей властивостей. Варто зазначити, що організація в закладах вищої освіти просресійної підготовки майбутніх учителів іноземної мови має певні особливості, які ґрунтуються на інтегрованому підході до забезпечення змісту навчально-виховного процесу. Ключові слова: підготовка, майбутній учитель іноземної мови, умови, педагогічні умови, компетентнісний підхід, професійна рефрлексія, інноваційні технології, професійна компетентність.
The essence of the concept "condition" is disclosed in the article and the content of the term "pedagogical conditions" is described. Based on a generalization of the existing scientific approaches of scientists, the concept of "pedagogical conditions for the preparation of future teachers of a foreign language for specialized education of senior pupils" is defined: the implementation of a competency-based approach in the process of modeling the content of preparation of future teachers of a foreign language for specialized training for high school students; introduction of innovative technologies in the process of forming professional competence of a future teacher of a foreign language; the formation of professional reflection of future teachers of a foreign language by means of self-assessment of readiness for specialized training of high school students.

In the context of problem's study, we consider the concept of "preparing future teachers of a foreign language" as a continuous, holistic, systemic and manageable educational process that ensures students are ready for professional and pedagogical activity and the formation of integrated personal education, containing in its structure motivational-value, cognitive-operational, reflective, active, personality components.

It is important to note that to characterize the concept of "professional and pedagogical readiness", scientists use the concept of "professional competence", which is defined as professional readiness and the ability of the subject of labor to perform tasks and responsibilities of everyday activities.

The result of preparing future teachers for profes sional activity is a certain level of readiness for professional activity, an active state of the personality, covering a positive attitude to the profession, abilities, knowledge, skills, stable professionally important qualities.

The professional readiness of the future teacher of a foreign language for pedagogical activity is characterized by his professional qualifications and a certain combination of personal qualities and properties. It is worth noting that the organization in higher education institutions of the professional training of future teachers of a foreign language has certain features based on an integrated approach to ensuring the content of the educational process.

Key words: training, future teacher of a foreign language, conditions, pedagogical conditions, competency-based approach, professional reflection, innovative technologies, professional

competence. викладач кафедри іноземних мов Міжнародного класичного університету імені Пилипа Орлика
Постановка проблеми у загальному вигляді. Нові концептуальні засади модернізації змісту і структури освіти в Україні передбачають необхідність оптимізації профрільного навчання старшокласників, що створить сприятливі умови для задоволення освітніх потреб та інтересів учнів, формуючи їх орієнтації на той чи інший вид майбутньої профресійної діяльності. Отже, постає необхідність вирішення проблеми створення сучасних дидактичних моделей, які дадуть змогу 
реалізувати прогресивні ідеї нового Закону України «Про освіту», однією з яких є ідея орієнтації на компетентнісний результат навчання.

Аналіз останніх досліджень і публікацій. В українській педагогічній літературі до проблеми формування особистості сучасного вчителя звертаються такі вчені, як І. Бех, О. Глузман, М. Євтух, І. Зязюн, В. Кремінь, Н. Ничкало, О. Савченко, І. Підласий, Н. Кузьміна та ін. У дослідженнях О. Барановської, Р. Безсонової, Н. Бібік, М. Бурди, Г. Васьківської, О. Васько, Г. Вороніної, М. Головка, В. Гузєєва, О. Дахіна, Ю. Дорошенка, Н. Зеленко, В. Кизенка, О. Корсакової, В. Кременя, Л. Липової, А. Самодрина, О. Топузова, С. Трубачевої та ін. з'ясовуються проблеми змісту профрільної освіти. Науковий пошук С. Бондар спрямований на розв'язання проблем профілізації старшої школи.

Виділення невирішених раніше частин загальної проблеми. Перед вищою школою стоїть важливе завдання - підготувати нову генерацію педагогічних кадрів для роботи в умовах розбудови Нової української школи, що зумовлює необхідність пошуку нових підходів до підготовки майбутніх учителів іноземної мови, найголовнішими рисами яких $€$ освіченість, комунікативна компетентність, самостійність, професійна мобільність, педагогічна майстерність, професійна зрілість, здатність до творчості, самоорганізації, саморозвитку, освіти впродовж життя.

Мета статті - розкрити сутність понять «умова», «педагогічні умови» та визначити педагогічні умови підготовки майбутніх учителів іноземної мови до профрільного навчання старшокласників.

Виклад основного матеріалу. Ефективність педагогічного процесу, на думку Ю. Бабанського, закономірнозалежитьвідумов, вякихвінпроходить.

Вивчення фрілософської та психолого-педагогічної літератури показує, що в науковій думці відсутній єдиний підхід щодо визначення понять «умова», «педагогічна умова». Великий тлумачний словник сучасної української мови надає слову «умова» кілька значень: необхідна обставина, що уможливлює здійснення, створення, утворення чого-небудь; обставини, особливості реальної дійсності, за яких відбувається або здійснюється що-небудь [3, с. 1506].

У психології поняття «умови» розглядається в площині психічного розвитку та корелюється із сукупністю внутрішніх і зовнішніх причин, що детермінують психологічний розвиток людини, прискорюють або уповільнюють його, впливають на процес розвитку, його динаміку та кінцеві результати; як певна обставина чи обстановка, що впливає на формування та розвиток педагогічних явищ, процесів, систем, якостей особистості [6, с. 97].

Отже, поняття «умова» у педагогіці розуміється вченими як: сукупність певних об'єктивних можливостей змісту навчання, методів, організаційних засобів фрактів, обставин, фракторів, впливів, процесів, заходів навчально-виховного процесу; система певних фрорм, методів, матеріальних умов, реальних ситуацій, що об'єктивно склалися, чи суб'єктивно створених, необхідних для досягнення конкретної педагогічної мети. У педагогічних дослідженнях здебільшого розглядається термін «педагогічні умови», незважаючи на різне тлумачення вченими зазначеного поняття, є спільні підходи.

На думку І. Підласого, педагогічні умови $€$ значущими продуктивними причинами, які впливають на протікання і результат дидактичного процесу і можуть прискорювати або гальмувати розвиток та формування педагогічних систем, процесів, явищ, якостей особистості [11, с. 25].

Вчені С. Гончаренко та Н. Ничкало вважають, що «педагогічні умови» $€$ обставинами, від яких залежить та відбувається цілісний продуктивний педагогічний процес профресійної підготовки фахівців, що опосередковується активністю особистості» [12, с. 143]

Визначаючи зміст зазначеного вище поняття, В. Манько акцентує на забезпеченні високої результативності навчального процесу і відповідності психолого-педагогічним критеріям оптимальності взаємозв'язаної сукупності внутрішніх параметрів і зовнішніх характеристик фрункціонування [8, с. 153-161].

На переконання М. Марусенко, зазначене вище поняття $€$ «дієвим елементом педагогічної системи, сукупністю взаємопов'язаних і взаємозумовлених заходів, які спрямовані на досягнення конкретної педагогічної мети» [9, с. 258].

Аналіз підходів учених до розуміння категорії «педагогічні умови» дає підстави зробити висновок, що зазначений феномен є комплексом, сукупністю обставин.

3 огляду на зазначене вище та в контексті проблеми дослідження педагогічні умови - це створене у ЗВО освітнє середовище, яке забезпечує цілісність і продуктивність освітнього процесу, результатом якого є високий рівень професійної готовності майбутнього вчителя іноземної мови до профрільного навчання старшокласників.

Враховуючи підходи науковців до розуміння категорії «педагогічні умови» та структуру профресійної готовності майбутнього вчителя іноземної мови до профрільного навчання старшокласників, ми визначили такі педагогічні умови підготовки майбутніх учителів іноземної мови до профрільного навчання старшокласників:

1) реалізація компетентнісного підходу у процесі моделювання змісту підготовки майбутніх учителів іноземної мови до профрільного навчання старшокласників;

2) підвищення рівня професійної компетентності викладачів вищого навчального закладу щодо впровадження інноваційних технологій 
у процес підготовки майбутнього вчителя іноземної мови до профільного навчання старшокласників;

3) фрормування профресійної рефлексії майбутніх учителів іноземної мови засобами самооцінки готовності до профрільного навчання старшокласників.

Обґрунтуємо зазначені вище педагогічні умови. Перша педагогічна умова заснована на ідеях компетентнісного підходу у відповідних державних документах: у Законі України «Про вищу освіту», «Національній доктрині розвитку освіти в Україні у XXI столітті», Положенні «Про освітньо-кваліфрікаційні рівні (ступеневу освіту)», Положенні «Про організацію навчального процесу у вищих навчальних закладах» та інших, а також у рекомендаціях Ради Європи щодо стратегії рефрормування вітчизняної системи освіти. Одним із напрямів модернізації професійної підготовки педагога згідно з матеріалами Симпозіуму ради Європи є застосування компетентнісного підходу.

На переконання І. Беха, «умовою і засобом реалізації профресії є людина-профресіонал, в особистості якої, з одного боку, втілюється те спільне, що характерне для будь-якого працівника, який зайнятий цим видом праці, а $з$ іншого - індивідуальне, привнесене ним самим у кожен конкретний акт, кожен аспект професійної діяльності» [1, с. 48-49].

Впровадження компетентнісного підходу до професійної освіти забезпечує перехід від її орієнтації на відтворення знань до їх практичного застосування [5, с. 11].

3 позицій компетентнісного підходу рівень освіти має визначатися здатністю фахівця вирішувати проблеми різної складності на основі наявних знань та досвіду. У процесі фрахової підготовки майбутніх учителів іноземної мови при компетентнісному підході акцентовано на практичній складовій частині освіти, що передбачає необхідність використання знань під час вирішення нестандартних ситуацій у професійній діяльності.

Таким чином, компетентнісний підхід нині відображає інноваційну тенденцію в розвитку освіти та $є$ радикальним засобом ії модернізації, умовою і способом досягнення її нової якості підготовки студентів до профресійної діяльності.

Другоюпедагогічноюумовоюєпідвищення рівня професійної компетентності викладачів вищого навчального закладу щодо впровадження інноваційних технологій у процес підготовки майбутнього вчителя іноземної мови до профільного навчання старшокласників. У сучасних умовах вимог суспільства до професійної освіти, впровадження нових освітніх стандартів та компетентнісного підходу актуальним є вибір викладачами ВНЗ таких технологій фрормування фрахової компетентності майбутніх учителів іноземної мови, які спрямовані на фрормування уміння працювати в команді, ана- лізувати ситуацію, самостійно приймати рішення $[13$, c. 316]

На думку Ю. Бистрова, поняття «інноваційні методики викладання» характеризуються полікомпонентністю, оскільки об'єднують нові й ефективні способи освітнього процесу, які сприяють інтенсиорікації та модернізації навчання, розвивають творчий підхід і особистісний потенціал здобувачів вищої освіти [2, с. 27-33].

Дослідниця В. Киливник акцентує на умовах досягнення ефективності під час оптимального поєднання традиційних методів навчання з інноваційними з метою підготовки майбутнього вчителя іноземної мови до профрільного навчання старшокласників: доцільності інноваційних технологій відповідно до індивідуальних особливостей студентів та рівня сорормованості їх соціокультурної компетентності чи якогось із компонентів; чіткого фрормулювання мети, що може бути досягнута лише 3 поєднанням методів; високому рівні педагогічної майстерності викладача вищого педагогічного навчального закладу [4, с. 164].

Отже, метою використання інноваційних технологій у процесі підготовки майбутнього вчителя іноземної мови є оновлення викладачами педагогічного процесу, внесення новоутворень у традиційну систему навчання, результатом яких є підвищення якості профресійної освіти студентів.

Третя педагогічна умова: формування профресійної рефлексії майбутніх учителів іноземної мови засобами самооцінки готовності до профрільного навчання старшокласників сприяє становленню оцінного ставлення студента до рівня готовності до майбутньої діяльності.

На думку В. Сластьоніна, зазначена вище категорія містить у собі також готовність діяти в ситуаціях із високим рівнем невизначеності, гнучкість у прийнятті рішень, прагнення до реалізації нововведень і інновацій, постійну спрямованість на пошук нових, нестандартних шляхів розв'язання професійних завдань, здатність переосмислювати свій професійний і особистісний досвід.

Профресійна рефлексія $€$ специфрічним механізмом, який може бути використаний у технології професійного самовизначення й становлення, оскільки високий рівень їі сорормованості $€$ показником переходу професійної діяльності на особистісно-смисловий рівень, чинником актуалізації розвитку професійної культури. За результатами дослідження В. Максименка, у професійно-педагогічній діяльності рефлексія необхідна як у процесі безпосередньої практичної взаємодії вчителя з учнями, коли вчитель прагне адекватно зрозуміти і цілеспрямовано регулювати їх вчинки почуття і мисленнєві процеси, так і в процесі проектування діяльності, визначення мети навчання і виховання та засобів їх досягнення з огляду на індивідуально психологічні особливості і можливості розвитку 
школярів, а також самоаналізу й самооцінки власної діяльності як її суб'єкта [7, с. 10].

Отже, стосовно процесу становлення особистості майбутнього вчителя, рефлексія набуває своєї специфіки і рис, зумовлених характером педагогічної діяльності, яка полягає в постійному рефлексивному аналізі педагогічних ситуацій, розумінні контексту як власних дій, так і дій іншої людини. На нашу думку, важливою умовою забезпечення такого процесу навчання в педагогічному ВН3 є його спрямування на фрормування професійної рефлексії майбутніх учителів. Адже, як зазначає В. Орлов, освітній ефект залежить від рівня самопізнання особистості, тому засвоєння знань має завершуватися не лише їх узагальненням і систематизацією, а й рефлексією суб'єктів навчально-виховного процесу [10, с. 77].

У цьому контексті профресійна рефлексія педагога визначається як якісна характеристика суб'єкта діяльності, що перетворює світ, носія свідомості й самосвідомості, що усвідомлює специфріку свого профресійного «Я», осмислює процес і результати педагогічної діяльності, аналізує свій стиль діяльності та його співвідношення 3 діяльністю учнів, оцінює адекватність обраної стратегії, вміє аналізувати та виправляти недоліки з метою підвищення еорективності розв'язання творчих педагогічних завдань.

Таким чином, запропоновані педагогічні умови та засоби їх реалізації ми вважаємо доцільними та науково відповідними досліджуваному френомену. На нашу думку, перелічені вище педагогічні умови підготовки майбутнього вчителя іноземної мови до профільного навчання старшокласників мають реалізовуватися як у процесі викладання фрахових дисциплін, так і в процесі викладання дисциплін психолого-педагогічного циклу.

Висновки. Таким чином, вважаємо, що створення вищезазначених педагогічних умов сприятиме забезпеченню високого рівня профресій- ної готовності майбутніх учителів іноземної мови до профрільного навчання старшокласників.

\section{БІБЛІОГРАФІЧНИЙ СПИСОК:}

1. Бех І. Становлення профресіоналізму в сучасних соціальних умовах. Педагогіка толерантності. 2001. № 3-4.

2. Бистрова Ю.В. Інноваційні методи навчання у вищій школі України. Право та інноваційне суспільство. 2015. №1 (4). С. 27-33.

3. Великий тлумачний словник сучасної української мови (з дод., допов.) / уклад. і голов. ред. В.Т. Бусел. Київ; Ірпінь : ВТФ, «Перун», 2009. 1736 с.

4. Киливник В. Педагогічні умови формування соціокультурної компетентності майбутніх учителів іноземної мови. Педагогічні науки: теорія, історія, інноваційні технології. 2018. № 2 (76). С. 156-166.

5. Компетентнісний підхід у сучасній освіті: світовий досвід та українські перспективи: Бібліотека з освітньої політики : монографрія / ред. О.В. Овчарук. Київ : К. І. С., 2004. 112 с.

6. Краткий психологический словарь / ред.-сост. Л. Карпенко; под общ. ред. А. Петровского, М. Ярошевского. Ростов-наДону : Фенікс, 1998. 512 с.

7. Максименко В. Рефрлексія шлях до продуктивного самовизначення. Психолог. 2005. № 1. С. 19-22.

8. Манько В.М. Дидактичні умови формування у курсантів просресійно-пізнавального інтересу до спеціальних дисциплін. Соціалізація особистості : збірник наук. пр. нац. пед. ун-ту ім. М. Драгоманова. Київ : Логос, 2000. Вип. 2. С. 153-161.

9. Марусенко М. Педагогічні умови фрормування профресійної рефрлексії майбутніх учителів початкових класів. Наука іосвіта. 2011. № 4. С. 257-261.

10.Орлов В.Ф. Професійне становлення вчителів мистецьких дисциплін : монографрія / за заг ред. І.А. Зязюна. Київ : Наук. думка, 103. 276 с.

11. Подласый И. Педагогика. Просвещение. Гуманитарный изд. Центр "Владос", 1996. 432 с.

12. Професійна освіта: словник : навч. посібник / уклад. С. Гончаренко та. ін; за ред. Н. Ничкало. Київ : Вища шк., 2000. 380 с.

13. Сучасні педагогічні технології / А.С. Нісімчук, О.С. Падалка, О.Т. Шпак. Київ, 2000. 368 с. 